\title{
Penerapan Model Pembelajaran Induktif dengan Pendekatan Analogi Dalam Upaya Meningkatkan Prestasi Belajar Teknologi Layanan Jaringan
}

\author{
Ni Ketut Mertasih ${ }^{1}$ \\ ${ }^{1}$ sekolah Menengah Kejuruan 1 Denpasar \\ Bali, Indonesia \\ e-mail: mertasih69@gmail.com ${ }^{1}$
}

\begin{abstract}
Abstrak
Penelitian ini bertujuan untuk: (1) mengetahui apakah Penerapan Model Pembelajaran Induktif dengan Pendekatan Analogi dapat Meningkatkan Prestasi Belajar Mata Pelajaran Teknologi Layanan Jaringan. Subyek Penelitian ini adalah peserta didik Kelas XI Kompetensi KeahlianTeknik Komputer Jaringan dengan jumlah 32 orang. Jenis data yang dikumpulkan dalam penelitian ini berupa: Data tentang prestasi belajar dan data respons peserta didik. Data tentang prestasi belajar diperoleh dengan cara memberikan tes dan hasil observasi belajar, sedangkan data respons peserta didik diperoleh dengan cara memberikan angket/kuesioner. Data hasil penelitian di analisis dengan metode statistik deskriptif. Berdasarkan hasil analisis data prestasi belajar ditemukan bahwa: (1)Terdapat peningkatan prestasi belajar peserta didik Kelas XI Kompetensi Keahlian Teknik Komputer Jaringan SMK Negeri 1 Denpasar yaitu pada siklus I jumlah peserta didik mencapai kompetensi adalah $81,25 \%$ dengan daya serap $76,40 \%$ sedangkan pada siklus II meningkat menjadi 93,75\% dengan daya serap 78,37\%. (2) Terdapat respons positif pada peserta didik Kelas XI Kompetensi Keahlian Teknik Komputer Jaringan SMK Negeri 1 Denpasar terhadap implementasi model pembelajaran induktif dengan pendekatan analogi pada proses pembelajaran.
\end{abstract}

Kata Kunci: pembelajaran induktif, pendekatan analogi, prestasi

\begin{abstract}
The aim of this research was: (1) to find out whether the application of Inductive Learning Model with the Analogy Approach could improve Learning Achievement in Technology Services for Network Services. The number of subject in this research was 32 students. The data were analyzed by using descriptive statistic. Based on the results of the analysis, it was found that: (1) there was an improvement on the learning achievement of students in Class XI on Computer Engineering Skills in SMK Negeri 1 Denpasar. On the first cycle, the students learning achievement was $81.25 \%$ with absorption of $76.40 \%$ while on the second cycle improved to $93.75 \%$ with absorption $78.37 \%$. (2) There was a positive response on the students of Class XI on Computer Network Engineering Skills Competency in SMK Negeri 1 Denpasar toward the implementation of inductive learning model with an analogy approach to the learning process. The result of the observation data analysis and the students' learning test scores showed that there was good results and the result of the students' responses to the application of the inductive learning model showed positive response, because it was ranged on a scale of 85-94. It could be concluded that the application of the inductive learning model with an analogy approach could improve the learning achievement of students in Class XI on Computer Engineering.
\end{abstract}

Keywords: inductive learning model, analogy approach

*Corresponding author.

Received 20 January 2020, Accepted 20 March 2020; Available online 5 Appril 2020 (C) 2020 MI All Rights Reserved 


\section{Pendahuluan}

Pendidikan adalah upaya sadar dan terencana dalam proses pembimbingan dan pembelajaran bagi individu agar tumbuh berkembang menjadi manusia yang mandiri, bertanggung jawab, kreatif, berilmu sehat dan berakhlak (berkarakter) mulia (UU No. 20 tahun 2003). Maka dari itu, pendidkan nasional mengemban misi yang sangat mulia yaitu membangun manusia seutuhnya. Untuk menjadikan bangsa dengan jati diri yang utuh, dibutuhkan sistem pendidikan yang memiliki materi holistik, serta ditopang oleh pengolahan dan pelaksanaan yang baik. Oleh karena itu pendidikan nasional harus bermutu dan berkarakter (Suyadi, 2013). Untuk mewujudkan manuasia yang seutuhnya diperlukan kerja keras oleh semua pihak melaui proses pembelajaran.

Proses pembelajaran merupakan sebuah upaya bersama antara guru dan peserta didik untuk berbagi dan mengolah informasi, dengan harapan pengetahuan yang diberikan bermanfaat dalam diri peserta didik dan menjadi landasan belajar yang berkelanjutan. Dengan demikian guru sebagai tenaga pendidik profesional diharapkan mampu mengembangkan aktivitas belajar peserta didik, baik aktivitas fisik maupun aktivitas mental peserta didik untuk menciptakan suatu proses pembelajaran yang berkualitas. Semua aktivitas peserta didik dapat dilihat dari keterlibatan atau partisipasi peserta didik di dalam proses pembelajaran. Pembelajaran adalah suatu yang memiliki posisi penting di dalam peningkatan mutu suatu pendidikan, oleh karena itu pencarian suatu pendekatan dalam model pembelajaran yang dapat meningkatkan mutu pendidikan menjadi keharusan yang dilakukan oleh seorang guru. Hal ini dikarenakan kebersilan dalam proses pembelajaran salah satunya ditentukan oleh ketepatan guru dalam memilih model dan pendekatan dalam pembelajaran. Dalam pemilihan model dan pendekatan ini tentunya disesuaikan dengan materi, situasi dan kondisi serta karakteristik dari peserta didik itu sendiri.

Dewasa ini banyak pendekatan dan model pembelajaran yang telah dikembangkan di dalam upaya meningkatkan mutu pendidikan, tetapi untuk mengetahui seberapa efektif dan efisien pendekatan dan model itu di dalam meningkatkan mutu pendidikan, memerlukan penelaahan lebih lanjut. Berbagai upaya yang dilakukan guru di sekolah untuk meningkatkan prestasi belajar peserta didik sehingga tujuan pendidikan dapat tercapai. Salah satunya adalah guru harus terampil menggunakan model pembelajaran dan pendekatan pembelajaran, pada saat proses pembelajaran berlangsung sehingga mudah dalam memahami materi-materi yang sedang dipelajari dan dapat diimplementasikan dalam berbagai masalah dalam pembelajaran.

Salah satu upaya yang efektif dapat dilakukan untuk memotivasi dan mengembangkan minat belajar peserta didik pada Mata Pelajaran Teknologi Layanan Jaringan adalah melalui pembelajaran induktif, dimana seorang guru memulai pembelajaran dengan memperkenalkan para peserta didik dengan suatu tantangan spesifik, seperti data bersifat percobaan untuk diinterpretasikan, suatu studi kasus untuk diteliti, atau suatu masalah kompleks dunia nyata untuk dipecahkan. Peserta didik yang mendapat tantangan ini akan cepat mengetahui kebutuhan akan fakta, keterampilan, dan pemahaman konseptual, dimana fungsi seorang guru adalah menyediakan intruksi atau membantu para peserta didik belajar secara mandiri.

Model pembelajaran induktif dengan pendekatan analogi dipandang tepat diterapkan di SMK Negeri 1 Denpasar khususnya pada Kelas XI Kompetensi Keahlian Teknik Komputer Jaringan, mengingat kelas bersangkutan mempunyai tingkat kemampuan kognitif lebih baik dibandingkan dengan kelas XI lainnya. Kemampuan kognitif ini dipandang tepat untuk dikembangkan melalui penerapan model pembelajaran induktif dengan pendekatan analogi.

Berdasarkan observasi yang dilakukan di Kelas XI Kompetensi Keahlian Teknik Komputer dan Jaringan Mata Pelajaran Teknologi Layanan Jaringan yang memiliki kemampuan kognitif yang cukup baik dengan prosentase ketuntasan $65 \%$ dan rata-rata 70,56 terlihat situasi kelas masih pasif, peserta didik kurang aktif dalam bertanya, menjawab 
pertanyaan, serta merespons penjelasan guru sehingga pembelajaran masih cenderung didominasi oleh guru. Hal ini menunjukan bahwa kemampuan kognitif harus diselaraskan dengan aktivitas dan kreativitas peserta didik, mengarahkan dan memotivasi peserta didik untuk berinovasi. Kondisi tersebut dipandang penting untuk mendapatkan tindakan yang tepat. Model pembelajaran induktif dengan pendekatan analogi diharapkan dapat mengatasi permasalahan tersebut sehingga dapat meningkatkan prestasi Belajar Mata Pelajaran Teknologi Layanan Jaringan peserta didik, serta dapat mencapai standar pencapaian minimum yang ditentukan.

Berdasarkan uraian di atas penulis mencoba melakukan penelitian yang berjudul Penerapan Model Pembelajaran Induktif dengan Pendekatan Analogi untuk Meningkatkan Prestasi Belajar Mata Pelajaran Teknologi Layanan Jaringan Kompetensi KeahlianTeknik Komputer Jaringan SMK Negeri 1 Denpasar Tahun Pelajaran 2019/2020.

\section{Metode}

Pada penelitian ini, peneliti menggunakan metode penelitian tindakan kelas dengan tahapan-tahapan pelaksanaan yang meliputi : perencanaan, pelaksanaan tindakan, pengamatan atau observasi, analisis, dan refleksi. Subjek penelitian adalah peserta didik Kelas XI Kompetensi Keahlian Teknik Komputer Jaringan SMK Negeri 1 Denpasar Kota Denpasar.

Berdasarkan rumusan masalah yang telah dikemukakan sebelumnya, maka variable penelitiannya ada tiga, yaitu model pembelajaran Induktif, Pendekatan Analogi, dan Prestasi Belajar pada Mata Pelajaran Teknologi Layanan Jaringan. Model pembelajaran induktif adalah model pembelajaran yang dikembangkan untuk meningkatkan kemampuan peserta didik dalam mengolah informasi dan berpikir kreatif. Dimana peserta didik belajar mengorganisasikan fakta ke dalam suatu sistem konsep. Pendekatan analogi adalah jembatan yang berfungsi untuk memudahkan pemahaman dan pengetahuan akan konsep dan target yang ingin dicapai dalam suatu pembelajaran. Sedangkan prestasi belajar yang dimaksud dalam penelitian ini adalah penguasaan konsep yang ditunjukkan melalui skor tes hasil belajar.

Pelaksanaan penelitian tindakan kelas ini mengambil waktu dalam dua siklus, yang mana tiap siklus memiliki tahapan sebagai berikut: 1) tahap perencanaan, 2) tahap pelaksanaan tindakan, 3) tahap pengamatan dan pengumpulan data, 4) tahap refleksi. Siklus I dan II berlangsung sebanyak empat kali pertemuan (24 jam pelajaran). Adapun desain model penelitian yang akan digunakan selama penelitian ini, adalah :

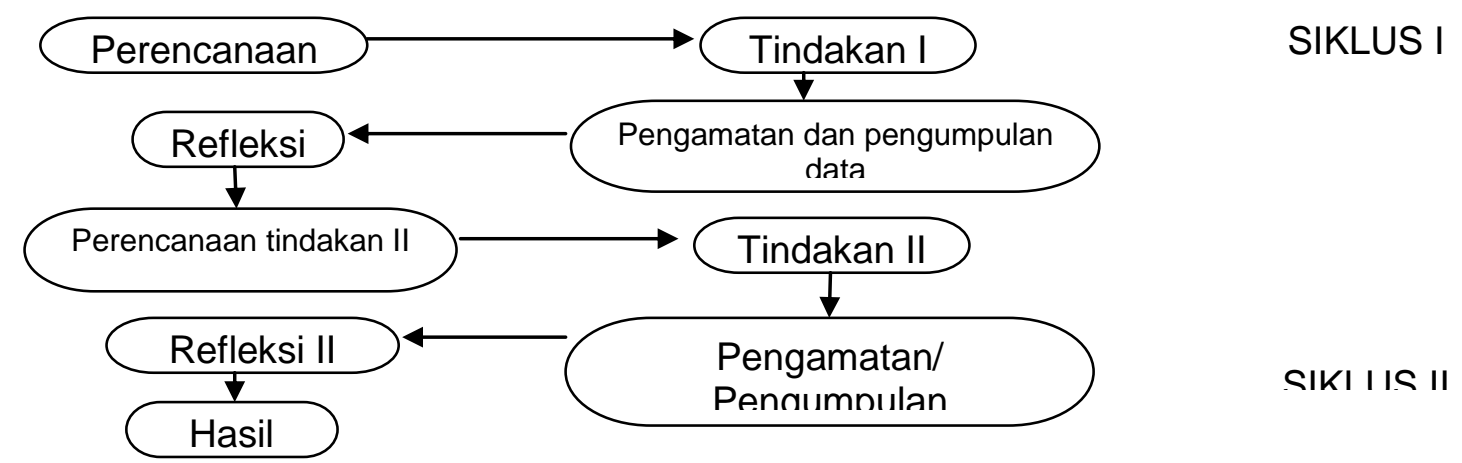

Gambar 01

Siklus Penelitian Tindakan Kelas 
Tahap perencanaan. 1) Melakukan diskusi dengan guru mata Pelajaran Mata Pelajaran Teknologi Layanan Jaringan pada sekolah tempat penelitian untuk membahas materi yang akan diajarkan. 2) Menentukan pokok bahasan yang akan diajarkan pada pelaksanaan siklus I melalui pembelajaran induktif dengan pendekatan analogi. 3) Mempersiapkan perangkat pembelajaran untuk delapan kali pertemuan. 4) Menyusun format lembar observasi dan. 5) Menyiapkan tes hasil belajar untuk digunakan pada akhir pelaksanaan kegiatan.

Tahap pelaksanaan penelitian ini ditunjukkan dalam tabel dibawah ini.

Tabel 01. Tabel pelaksaan kegitan

\begin{tabular}{|c|c|c|c|}
\hline \multicolumn{4}{|c|}{ Tahap Pertama: Pembentukan Konsep } \\
\hline Pertama & Kedua & Ketiga & \\
\hline $\begin{array}{l}\text { Menidentifikasi } \\
\text { menyebutkan data satu } \\
\text { persatu. Data yang relevan } \\
\text { dimaksukkan ke dalam topik } \\
\text { atau masalah }\end{array}$ & $\begin{array}{l}\text { Mengelompokkan data dalam } \\
\text { katagori yang sejenis }\end{array}$ & $\begin{array}{l}\text { Mengkatagorikan } \\
\text { memberi nama } \\
\text { tersebut }\end{array}$ & $\begin{array}{r}\text { dan } \\
\text { katagori }\end{array}$ \\
\hline \multicolumn{4}{|c|}{ Tahap kedua: Interprestasi Data } \\
\hline $\begin{array}{l}\text { Mengidentifikasi butir-butir } \\
\text { informasi atau data yang } \\
\text { saling berhubungan }\end{array}$ & 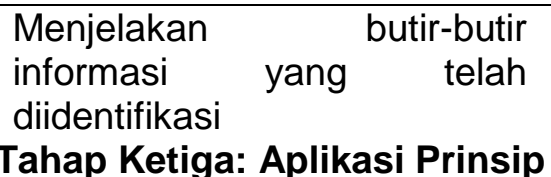 & Membuat kesimpulan & \\
\hline Pertama & Kedua & Ketiga & \\
\hline $\begin{array}{l}\text { Menganalisis masalah. } \\
\text { Menjelaskan fenomena dan } \\
\text { menyusun hipotesis }\end{array}$ & $\begin{array}{l}\text { Menjelaskan atau mendukung } \\
\text { hipotesis }\end{array}$ & Menuji perkiraan & \\
\hline
\end{tabular}

Tahap observasi dilaksanakan pada saat pemberian tindakan berlangsung. Adapun aspek yang diobservasi untuk aktivitas peserta didik, Orientasi peserta didik pada masalah, meliputi; proses belajar, interaksi sosial, kemampuan kelompok, kemampuan individu, dan penalaran. Refleksi dilakukan pada setiap siklus, berdasarkan hasil analisis data yang diperoleh pada tahap observasi, Hasil refleksi selanjutnya dijadikan pertimbangan untuk membuat perencanaan untuk siklus II.

Pengumpulan data yang dilakukan dalam penelitian ini adalah sebagai berikut : Data hasil belajar peserta didik dikumpulkan melalui tes hasil belajar dalam bentuk essay tes, data aktivitas peserta didik dan aktifitas guru dikumpulkan melalui observasi. Data yang terkumpul dianalisis dengan menggunakan analisis statistik deskriptif kualitatif. Indikator keberhasilan dari penelitian ini adalah minimal 85 persen peserta didik mencapai skor tes hasil belajar minimal 75.

\section{Hasil dan Pembahasan}

Berdasarkan penelitian yang telah dilakukan, terdapat peningkatan darisiklus I dan siklus II. Hal ini dapat dilihat dari nilai rata-rata prestasi belajar siswa yang meningkata dari 76,40 menjadi 78, 37. Secara terinci ditunjukan pada tabel 01 dan 02. 
Tabel 02. Prestasi Belajar Peserta Didik

\begin{tabular}{cccc}
\hline \multirow{2}{*}{ siklus } & \multicolumn{3}{c}{ Skor perolehan peserta didik } \\
& Skor tertinggi & Skor terndah & Rata-rata \\
\hline I & 85,00 & 60,00 & 76,40 \\
II & 90,00 & 70,00 & 78,37 \\
\hline
\end{tabular}

Tabel 03 Ketuntasan Belajar Peserta Didik

Siklus

\section{Frekuensi}

Tuntas

।

26

30
Tidak Tuntas
6

2
Pessentas (\%)

Tuntas

81,25

93,75
18,75

Tidak Tuntas

6,25

Dari tabel 4.1, tampak bahwa dari 32 orang peserta didik SMK Negeri 1 Denpasar Kota Denpasar yang menjadi subjek penelitian dapat diuraikan sebagai berikut :

$81,25 \%$ peserta didik Kelas XI Kompetensi Keahlian Teknik Komputer Jaringan SMK Negeri 1 Denpasar Kota Denpasar dikategorikan tuntas pada siklus 1 dan meningkat menjadi $93,75 \%$ pada siklus 2. 18,75\% peserta didik Kelas XI Kompetensi KeahlianTeknik Komputer Jaringan SMK Negeri 1 Denpasar dikategorikan tidak tuntas menjadi 6,25\% pada siklus 2.

Hasil ini menunjukkan bahwa Prestasi Belajar Mata Pelajaran Komputer peserta didik Kelas XI Kompetensi Keahlian Teknik Komputer Jaringan SMK Negeri 1 Denpasar dalam mengikuti pembelajaran mata Pelajaran Teknologi Layanan Jaringan melalui penerapan pembelajaran induktif dengan pendekatan analogi pada siklus 2 telah mencapai target indikator keberhasilan dalam penelitian yaitu $93,75 \%$ yang memiliki nilai di atas KKM lebih dari $85 \%$ yang ditargetkan. Hal ini menunjukkan bahwa pembelajaran mata Pelajaran Teknologi Layanan Jaringan dengan menggunakan pembelajaran induktif dengan pendekatan analogi pada siklus 2 berhasil meningkatkan hasil belajar peserta didik dalam Mata Pelajaran Teknologi Layanan Jaringan Kelas XI Kompetensi Keahlian Teknik Komputer Jaringan SMK Negeri 1 Denpasar Tahun 2019/2020.

Dari hasil evaluasi kegiatan di siklus 1 menunjukkan bahwa terdapat 18,75\% peserta didik Kelas XI Kompetensi KeahlianTeknik Komputer Jaringan SMK Negeri 1 Denpasar Tahun Pelajaran 2019/2020 belum mencapai ketuntasan belajar minimum, sedangkan pada siklus 2 menjadi $6,25 \%$.

Dari perbandingan hasil observasi pada siklus I dan siklus II jika dilihat dari persentase perolehan maka dapat dikatakan bahwa terjadi peningkatan aktivitas peserta didik. Keberhasilan tersebut antara lain disebabkan oleh usaha yang dilakukan dimana peneliti hadir adalah untuk membantu peserta didik dalam memecahkan masalah sampai analisis dan penyajian dalam model yang lebih menarik dibandingkan pembelajaran yang biasa dilakukan dan penggunaan media power point untuk mendukung praktikum analisis pada siklus II. Hal ini membuat peserta didik kreatif dan berusaha mencari sendiri jawaban dari permasalahan yang dimunculkan, sehingga peserta didik dapat lebih memahami kompetensi yang diajarkan karena mereka yang menemukannya sendiri (bermakna).

Model pembelajaran induktif memiliki makna bagaimana sebuah model pembelajaran dapat dikembangkan dan dikreasikan untuk meningkatkan kemampuan peserta didik dalam mengolah informasi dan berpikir kreatif. Dimana peserta didik belajar mengorganisasikan fakta 
ke dalam suatu sistem konsep, yaitu (a) menghubung- hubungkan data yang diperoleh satu sama lain serta membuat kesimpulan berdasarkan hubungan-hubungan tersebut, (b) menarik kesimpulan berdasarkan atas realitas dan fakta-fakta yang diketahuinya dalam rangka membangun hipotesis, dan (c) memprediksi dan memperjelas suatu fenomena tertentu. Guru dalam hal ini membantu proses penghayatan dan konseptualisasi berdasarkan informasi tersebut. Pada model pembelajaran induktif lebih mengarahkan peserta didik untuk berpikir secara induktif yang mana memerlukan strategi khusus dalam proses pencapaiannya. Dalam proses pembelajaran peneliti menggunakan tiga strategi atau cara mengajarkannya, yaitu pertama adalah pembentukan konsep (concept formation) sebagai strategi dasar; kedua interpretasi data (data interpretation) dan ketiga adalah penerapan prinsip (application of principles).

Model pembelajaran induktif mensyaratkan sebuah lingkungan belajar yang mana di dalamnya peserta didik merasa bebas dan terlepas dari resiko takut dan malu saat memberikan pendapat, bertanya, mengemukakan hasil kesimpulan dan jawaban. Mereka harus bebas dari kritik tajam yang dapat menjatuhkan semangat belajar. Dalam model pembelajaran induktif, peran utama guru dalam pelaksanaan pembelajaran adalah sebagai pemonitor cara-cara peserta didik mengalami proses informasi.

Dalam pembelajaran induktif penyajiannya terbagi atas lima tahap, yaitu: (1) fase pengenalan pelajaran, (2) fase terbuka, (3) fase konvergen, (4) fase penutup, dan (5) fase aplikasi. Pengelolaan pembelajaran yang dilakukan oleh guru setiap fase pembelajaran model induktif adalah sebagai berikut. 1) Fase pengenalan pelajaran yang terdiri atas; memotivasi peserta didik, menghubungkan pengetahuan awal pesertadidik dengan pokok bahasan, memberitahukan tujuan tujuan pembelajaran, menginformasikan secara garis besar kegiatan yang akan dilaksanakan oleh peserta didik selama proses pembelajaran. 2) Fase terbuka yang terdiri atas; memberi contoh yang sesuai dengan pokok bahasan dan tujuan pembelajaran, membimbing peserta didik melakukan observasi dengan pertanyaan terbuka. 3) Fase konvergen yang terdiri atas; membimbing peserta didik dalam menyajikan pengamatan, membimbing diskusi. 4) Fase penutup yang terdiri atas; membimbing peserta didik dalam merumuskan simpulan. 5) Fase aplikasi yang terdiri atas; membimbing peserta didik agar dapat memberi contoh aplikasi dari konsep.

Model pembelajaran induktif akan lebih efektif lagi diterapkan apabila digabungkan dengan pendekatan analogi. Dalam pendekatan analogi, ada diistilahkan sebagai konsep dan target. Konsep lebih dimaknai sebagai suatu materi yang akan dideskriptifkan secara konkrit dalam menggambarkan sesuatu agar dapat dipahami oleh peserta didik secara menyeluruh. Sedangkan target lebih dimaknai sebagai penalaran dan pemahaman baru yang lebih konkrit dimana menjadi bagian sempurna dari tujuan pembelajaran secara utuh. Dalam hal ini yang memerlukan pemahaman disebut target, sementara yang berfungsi sebagai referensi analogi disebut konsep. Sedangkan yang menjadi penghubung antara keduanya disebut analogi. Menurut Clement, (1995) bahwa target dalam pembelajaran analogi dapat disajikandalam bentuk verbal, gambar dan kombinasi antar verbal dan gambar. Model sederhana dari pendekatan pembelajaran analogi dapat digambarkan sebagi berikut:

Untuk membantu peserta didik dalam memahami kasus konsep dan kasus target, maka diperlukan suatu penghubung atau jembatan analogi. Jembatan analogi berfungsi untuk menghubugkan dan memudahkan pemahaman serta pengetahuan akan konsep dan target.

Secara khusus, dalam memecahkan masalah dan dalam penerapan ide-ide yang telah dipelajari untuk menghasilkan lebih lanjut ide-ide baru. Analogi dibuat untuk dapat memudahkan pemahaman terhadap pengetahuan yang baru dengan cara membandingkannya dengan pengetahuan yang sudah dikenal oleh peserta didik (Reiggeluth) dalam (Wena, 2009). Analogi menggambarkan persamaan antara pengetahuan yang baru dengan pengetahuan 
yang lain yang berada diluar cakupan pengetahuan yang sedang dipelajari. Di samping itu, analogi dipakai untuk memperjelas suatu konsep, prosedur, prinsip, atau teori sehingga mudah dipahami peserta didik.

Jadi pendekatan analogi dalam model pembelajaran induktif sangat bermanfaat karena pendekatan analogi ini sebagai jembatan yang berfungsi untuk memudahkan pemahaman dan pengetahuan akan konsep dan target yang ingin dicapai dalam suatu pembelajaran. Di dalam model ini, ide-ide dari suatu konsep yang akrab (analogi) bagi peserta didik ditrasferkan ke ideide yang tidak akrab (target). Jika analogi dan target memiliki beberapa kesamaan, suatu analogi dapat digambarkan antara ide-ide tersebut.

Belajar lebih ditekankan pada proses kegiatannya dan proses belajar lebih ditekankan pada hasil belajar yang dicapai oleh subjek belajar atau peserta didik. Hasil belajar dari kegiatan belajar disebut juga dengan prestasi belajar. Hasil atau prestasi belajar peserta didik dipakai sebagai ukuran untuk mengetahui sejauh mana peserta didik dapat menguasai bahan pembelajaran yang sudah dipelajari. Menurut Benjamin S. Bloom dalam Nurman (2006) prestasi belajar meliputi 3 aspek yaitu kognitif, afektif dan psikomotorik. Dalam penelitian ini yang ditinjau adalah aspek kognitif yang meliputi: pengetahuan, pemahaman, dan penerapan.

Prestasi belajar sebagai hasil dari proses belajar peserta didik biasanya pada setiap akhir semester atau akhir tahun ajaran yang disajikan dalam buku laporan prestasi belajar peserta didik atau rapor. Prestasi belajar mempunyai arti dan manfaat yang sangat penting bagi peserta didik, guru, wali murid dan sekolah, karena nilai atau angka yang diberikan merupakan manifestasi dari prestasi belajar peserta didik dan berguna dalam pengambilan keputusan atau kebijakan terhadap peserta didik yang bersangkutan maupun sekolah. Kemampuan peserta didik yang terukur, berupa pengetahuan, sikap dan keterampilan yang dicapai peserta didik dalam kegiatan pembelajaran merupakan definisi dari prestasi belajar.

Ditinjau dari makna atau pengertian prestasi atau hasil belajar di atas, dapat disimpulkan bahwa prestasi belajar adalah sebuah pola perubahan tingkah laku yang berwujud pada perubahan ilmu pengetahuan, keterampilan motorik, sikap dan nilai yang dapat diukur secara nyata sebagai hasil dari proses belajar. Dimana prestasi belajar peserta didik dapat diukur melalui instrument penilaian. Baik penilaian pada aspek kognitif, afektif dan psikomotoriknya.

Hasil penelitian ini sejalan dengan hasil penelitian yang dilakukan oleh Warsiman pada tahun 2011 yang berjudul PengembanganModel Induktif Dalam Pembelajaran Apresiasi Puisi. Hasil penelitian menunjukkan bahwa pembelajaran melalui model induktif yang memperhatikan delapan langkah pembelajaran tersebut dapat meningkatkan kemampuan siswa dalam mengapresiasi puisi. Peningkatan itu secara numerik dapat dilihat dari rata-rata hasil evaluasi dan rata-rata hasil observasi dalam setiap pemberlakuan. Pada pemberlakuan I rata-rata hasil evaluasi menunjukkan angka 60,9, pada pemberlakuan II menunjukkan angka 62,4, dan pada pemberlakuan III menunjukkan angka 65,3 , sedangkan rata-rata hasil observasi pada pemberlakuan I dari kriteria „,kurang" berangsur-angsur menjadi „cukup", pada pemberlakuan II dari kreteria "cukup" berangsur-angsur menjadi "baik" dan pada pemberlakuan III dari kriteria „baik" berangsur-angsur menjadi „sangat baik".

Selanjutnya penelitian yang dilakukan oleh Aisyah pada tahun 2016 yang berjudul Studi literatur: Pendekatan induktif untuk meningkatkan kemampuan generalisasi dan self confident siswa SMK. Hasil penelitiannya menyatakan bahwa pendekatan induktif dapat meningkatkan kemampuan generalisasi dan self confident siswa SMK. 


\section{Simpulan dan Saran}

Berdasarkan hasil penelitian dan pembehasan dapat disimpulkan beberapa hal sebagai berikut. 1) Terdapat peningkatan prestasi belajar peserta didik Kelas XI Kompetensi KeahlianTeknik Komputer Jaringan SMK Negeri 1 Denpasar yaitu; pada siklus I jumlah peserta didik mencapai kompetensi adalah $81,25 \%$ dengan daya serap $76,40 \%$, sedangkan pada siklus II meningkat menjadi $93,75 \%$ dengan daya serap 78,37\%. 2) Terdapat respons positif pada peserta didik Kelas XI Kompetensi Keahlian Teknik Komputer Jaringan SMK Negeri 1 Denpasar terhadap implementasi model pembelajaran induktif dengan pendekatan analogi pada proses pembelajaran.

Untuk meningkatkan prestasi Belajar Mata Pelajaran Teknologi Layanan Jaringan dengan menerapkan model pembelajaran induktif dengan pendekatan analogi direkomendasikan untuk menempuh langkah-langkah sebagai berikut : 1) Guru dapat menggunakan model pembelajaran induktif dengan pendekatan analogi sebagai salah satu alternatif model pembelajaran di sekolah. 2) Diharapkan dengan diterapkannya model pembelajaran induktif dengan pendekatan analogi dalam Pembelajaran Mata Pelajaran Teknologi Layanan Jaringan di SMK dapat memberikan suatu alternatif yang dapat digunakan untuk melaksanakan kegiatan pembelajaran. 3) Diharapkan kepada pembaca untuk mengadakan penelitian lebih lanjut mengenai penerapan model pembalajaran induktif dengan pendekatan analogi pada Pembelajaran Mata Pelajaran Teknologi Layanan Jaringan maupun pada pembelajaran lainnya.

\section{Daftar Pustaka}

Aisyah, Ani. 2016. Studi literatur: Pendekatan induktif untuk meningkatkan kemampuan generalisasi dan self confident siswa SMK. Jurnal Penelitian Pendidikan dan Pengajaran Matematika vol. 2 no. 1, pp. 1-12.

Clemens, H., Bean, R., Clack, A. 1995. Bagaimana Meningkatkan Harga Diri Remaja. Alih Bahasa: Tjandrasa, Meitasari, M. Jakarta. Penerbit: Bina Rupa Aksara. (Cetakan Pertama)

Dantes. 2008. Supervisi Akademik dalam Kaitannya dengan Penjaminan Mutu Pendidikan. Singaraja : Universitas Pendidikan Ganesha (Undiksha).

Faiq, Muhamad. 2009. Pembelajaran Induktif-Struktur Sosial dan Peran Guru. Kata kunci http://penelitiantindakankelas.blogspot.com/2009/03/model pembelajaran-induktifstruktur.html. Diunggah 04 Maret 2009.

Mahurianasla, 2011. Model Pembelajaran Induktif. Mahasiswa Pascasarjana (S2). Teknologi Pendidikan Unib. Kata kunci http://mahurianasla.blogspot.com/2011/02/modelpembelajaran-induktif.html. Diunggah 8 Mei 2011.

Nurman, 2006. Proses Belajar Mengajar. Bandung: Bumi Aksara.

Rusyana, 1998. Pendekatan Analogi. Perpustakaan Universitas Pendidikan Indonesia. Kata kunci http://pendekatan analogi.pdf. 
Suyadi. 2013. Strategi Pembelajaran Pendidikan Karakter. Bandung: PTRemaja Rosdakarya.

Warsiman. 2011. Pengembangan Model Induktif Dalam Pembelajaran Apresiasi Puisi. Jurnal Bahasa Dan Seni, Tahun 39, Nomor 1.

Wena, 2009. Strategi Pembelajaran Inovatif Kontemporer. Jakarta: Bumi Aksara. 